\title{
Effect of Sodium Intake on the Brain and the Aortic Angiotensin-Converting Enzyme Activity in Spontaneously Hypertensive Rat
}

\author{
Kenji Mizuno, M.D., Shyuichi Shigetomi, M.D., \\ Junichiro Matsur, M.D., and Soitsu Fukuchi, M.D.
}

\section{SUMmary}

Effecr of sodium intake on angiotensin-converting enzyme activity was studied in five areas of the brain (cerebral cortex, midbrain, striatum, thalamus and hypothalamus) and in subcellular fractions of the aorta (homogenate, mitochondria, microsomes and supernatant) in normotensive, spontaneously hypertensive, and stroke-prone spontaneously hypertensive rats. Angiotensin-converting enzyme activity was significantly higher in the hypothalamic area than in the other areas of the brain in spontaneously hypertensive rat. The enzyme activity of subcellular fractions of the aorta showed an extremely high value in the supernatant in normotensive, spontaneously hypertensive, and stroke-prone spontaneously hypertensive rats. Sodium intake resulted in a marked decrease in the aortic converting enzyme activity, while it did in a significant rise of the enzyme activity in the midbrain area in spontaneously hypertensive rat, and in the midbrain and striatum areas in stroke-prone spontaneously hypertensive rat. It is likely therefore that sodium intake lowers the converting enzyme activity of the aorta. Increased converting enzyme activity of the brain in spontaneously hypertensive rats may play a possible role in hypertension induced by sodium intake.

\section{Additional Indexing Words :}

Angiotensin-converting enzyme activity Brain Aorta Sodium intake Spontaneously hypertensive rat

A NGIOTENSIN-CONVERTING enzyme, a peptidyl-dipeptide hydroA lase, liberates the $\mathrm{C}$ terminal His-Leu dipeptide from angiotensin I transforming it to the active octapeptide, angiotensin II. This enzyme has been extensively studied in peripheral tissues ${ }^{1)}$ ) ) because of the importance of angiotensin II in hypertension.

Recently, there is increasing evidence that conversion of angiotensin I into II can occur in the renal vasculature of humans ${ }^{4)}$ and $\operatorname{dog}^{5)}$. In previous

From the Third Department of Internal Medicine, Fukushima Medical College, Fukushima.

Request for reprints: Dr. Kenji Mizuno, the Third Department of Internal Medicine, Fukushima Medical College Fukushima, 4-45 Sugitsuma-cho, Fukushima-shi, Fukushima, 960 Japan.

Received for publication December 5, 1980. 
experiments, the presence of specific angiotensin-converting enzyme in the brain of humans ${ }^{6)}$ and rat $^{7}$ has been demonstrated. On the other hand, literature dealing with the subcellular distribution of the enzyme activity of the aorta is rare. Furthermore, effect of sodium intake on the enzyme activity of the brain and the aorta is poorly described.

The purpose of the present study is to determine the subcellular distribution of the aortic converting enzyme activity and to investigate a role of sodium in this enzyme activity in these different tissues in the rats.

\section{Methods}

Female normotensive rats of Wistar-Kyoto strain (WKY), spontaneously hypertensive rats (HR) and stroke-prone SHR (SHR-SP), aged 20-21 weeks, were used. Each was divided into control group, fed on stock chow containing approximately $0.03 \% \mathrm{NaCl}$ (Oriental Co., Tokyo, Japan) and distilled water ad libitum, and experimental group treated with $1.0 \% \mathrm{NaCl}$ drinking solution for a period of 4 weeks. Body weights were determined and tail blood pressure was measured with an ultrasound device (Programmed electrosphygmomanometer PE 300, Narco) every week.

The rats were killed by decapitation without anesthesia, and the brains and the whole aortae were excized immediately. All subsequent procedures were carried out at $4^{\circ} \mathrm{C}$. The brains were separated into five areas, i.e. cerebral cortex, midbrain, striatum, thalamus and hypothalamus according to the procedure described by Glowinski. ${ }^{8)}$ Each was weighed and homogenized in 20 volumes of $0.01 \mathrm{M}$ potassium phosphate buffer $(\mathrm{pH} 7.4$ ) in a Potter-Elvehjem glass homogenizer fitted with a teflon pestle at $1500 \mathrm{rev}$./min with 20 up and down strokes. Then the homogenates were stored at $-20^{\circ} \mathrm{C}$ until assay of the converting enzyme activity. Aortic tissue was cleaned of containing blood with a moist saline gauge, stripped of surrounding tissue, including adventitia, briefly rinsed three to five times in sucrose solution $(0.25 \mathrm{~mol} / \mathrm{L})$ in volume to give a $10 \%$ homogenate. The homogenation procedure was carried out for $5 \mathrm{~s}$ at a time, with a 1 min rest period with a total homogenation time of $3 \mathrm{~min}$. The crude homogenate was subfractionated by differential ultracentrifugation according to the method by Rosenthal et al. ${ }^{9)}$ and the electron-microscopic appearance of the mitochondrial and microsomal fractions was similar to that described by Rosenthal et al. ${ }^{9)}$ Protein determinations were performed by the method of Lowry et al. $^{10)}$ for the five areas of the brain and the aortic subcellular fractions. Angiotensin-converting enzyme activity was measured by the spectrophotometric assay using hippuryl-1-histidyl-1leucine (Protein Research Foundation, Osaka, Japan) as substrate. The assay was performed by a modification of the method by Lieberman. ${ }^{11)}$ One unit of the enzyme activity is defined as one nanomole hippuric acid formed per min per $\mathrm{mg}$ of tissue protein at $37^{\circ} \mathrm{C}$. All assays were performed in duplicate; coefficients of variation (CV) were as follows: intraassay, $3.8 \%$, and interassay, $4.5 \%$. Angiotensinconverting enzyme activity from each fraction was stable for several months at $-20^{\circ} \mathrm{C}$. Results are presented as mean \pm SEM. For statistical analysis Student's t-test was used. 


\section{Results}

\section{Blood pressure}

In control rats, the systolic blood pressure did not change; from $104 \pm 12$ to $106 \pm 7 \mathrm{mmHg}$ in WKY, from $210 \pm 8$ to $212 \pm 4 \mathrm{mmHg}$ in $\mathrm{SHR}$, and from $216 \pm 14$ to $220 \pm 10 \mathrm{mmHg}$ in SHR-SP. The systolic blood pressure of WKY treated with $1.0 \% \mathrm{NaCl}$ solution for 4 weeks was $110 \pm 8 \mathrm{mmHg}$, which was approximately equal to that of the control WKY.

In contrast, the systolic blood pressure of SHR and SHR-SP treated with $1.0 \% \mathrm{NaCl}$ solution was $236 \pm 12$ and $244 \pm 8 \mathrm{mmHg}$ respectively.

2. Effect of sodium intake on the brain angiotensin-converting enzyme activity (Table 1)

In control WKY and SHR-SP, no significant difference in the enzyme activity was observed in all areas studied, i.e. cerebral cortex, striatum, midbrain, thalamus and hypothalamus. In control SHR, on the other hand, the enzyme activity in the hypothalamus was $10.4 \pm 2.7$ units, which was significantly higher than in the other areas of the brain $(p<0.05)$.

The enzyme activity in the midbrain of the treated SHR and SHR-SP was $6.1 \pm 1.3$ and $8.2 \pm 2.7$ units respectively, which was significantly higher than that in the same area of the control rats. In the treated SHR-SP, the enzyme activity of the striatum was remarkably high (13.2 \pm 2.9 units) and was also significantly higher than in the control rats.

No significant difference in the enzyme activity was observed in each brain area between the control and the treated WKY.

3. Effect of sodium intake on the aortic angiotensin-converting enzyme activity (Table 2)

Of the control rats, the converting enzyme activity of the crude homo-

Table I. Effect of Sodium Intake on Angiotensin-converting

Enzyme Activity in the Brain

\begin{tabular}{l|ccc|ccc}
\hline \multicolumn{1}{c|}{ Rat } & \multicolumn{3}{|c|}{ Control } & \multicolumn{3}{c}{ Sodium intake } \\
\cline { 2 - 6 } & $\begin{array}{c}\text { WKY } \\
(\mathrm{n}=10)\end{array}$ & $\begin{array}{c}\text { SHR } \\
(\mathrm{n}=10)\end{array}$ & $\begin{array}{c}\text { SHR-SP } \\
(\mathrm{n}=10)\end{array}$ & $\begin{array}{c}\text { WKY } \\
(\mathrm{n}=10)\end{array}$ & $\begin{array}{c}\text { SHR } \\
(\mathrm{n}=15)\end{array}$ & $\begin{array}{c}\text { SHR-SP } \\
(\mathrm{n}=15)\end{array}$ \\
\hline Cerbral cortex & $5.2 \pm 1.5$ & $4.7 \pm 1.7$ & $5.8 \pm 1.1$ & $2.9 \pm 2.1$ & $4.3 \pm 2.5$ & $3.2 \pm 2.1$ \\
Midbrain & $3.5 \pm 2.2$ & $3.8 \pm 0.7$ & $4.5 \pm 1.4$ & $7.2 \pm 3.1$ & $6.1 \pm 1.3 \#$ & $8.2 \pm 2.7 \#$ \\
Striatum & $5.5 \pm 3.1$ & $4.6 \pm 2.1$ & $3.9 \pm 1.5$ & $6.6 \pm 1.8$ & $5.1 \pm 2.2$ & $13.2 \pm 2.9 \# \#$ \\
Thalamus & $6.5 \pm 3.7$ & $2.8 \pm 0.9$ & $1.3 \pm 1.2$ & $6.1 \pm 2.9$ & $2.2 \pm 1.4$ & $1.7 \pm 0.4$ \\
Hypothalamus & $4.9 \pm 3.3$ & $10.4 \pm 2.6 *$ & $4.8 \pm 2.1$ & $5.7 \pm 2.2$ & $11.3 \pm 3.4$ & $4.7 \pm 1.9$
\end{tabular}

Each value is mean \pm S.E.M. for the rats. Number of rats is shown in parentheses.

Abbreviation used: WKY, Wistar-Kyoto rat; SHR, spontaneously hypertensive rats; SHR-SP, stroke-prone spontaneously hypertensive rats.

Significance of differences: * $\mathrm{p}<0.05$ as compared with the other areas of control SHR; \# $<<$ 0.05 , \# $\mathrm{p}<0.01$ as compared with the control values. 
genate in SHR-SP was $5.0 \pm 0.5$ units, which was significantly higher than that in WKY $(p<0.05)$ and in SHR $(p<0.01)$. In contrast, the enzyme activity in the microsomal fraction of SHR was significantly higher than in that of WKY $(p<0.05)$ and of SHR-SP $(p<0.05)$. The enzyme activity in the supernatant was the greatest of the subcellular fractions of aorta in each control rat. However, the enzyme activiy of the supernatant fraction of SHR and SHR-SP was significantly higher than that of WKY $(p<0.05)$. Total converting enzyme activity of SHR and SHR-SP was greater than in WKY by 38 and $14 \%$ respectively.

Sodium intake resulted in a marked decrease, bordering upon absence, of the converting enzyme activity in each fraction of the aorta in WKY, SHR and SHR-SP (Table 2).

Table II. Effect of Sodium Intake on Angiotensin-converting Enzyme Activity of the Aortic Subcellular Fractions

\begin{tabular}{l|ccc|ccc}
\hline \multirow{2}{*}{ Rat } & \multicolumn{3}{|c|}{ Control } & \multicolumn{3}{|c}{ Sodium intake } \\
\cline { 2 - 7 } & $\begin{array}{c}\text { WKY } \\
(\mathrm{n}=10)\end{array}$ & $\begin{array}{c}\text { SHR } \\
(\mathrm{n}=10)\end{array}$ & $\begin{array}{c}\text { SHR-SP } \\
(\mathrm{n}=10)\end{array}$ & $\begin{array}{c}\text { WKY } \\
(\mathrm{n}=10)\end{array}$ & $\begin{array}{c}\text { SHR } \\
(\mathrm{n}=15)\end{array}$ & $\begin{array}{c}\text { SHR-SP } \\
(\mathrm{n}=15)\end{array}$ \\
\hline Homogenate & $3.5 \pm 0.9$ & $2.0 \pm 0.2$ & $5.0 \pm 0.5+*$ & $0.3 \pm 0.1+\dagger$ & $0.0 \pm 0.0+\dagger$ & $0.0 \pm 0.0+\dagger$ \\
Mitochondria & $2.2 \pm 0.6$ & $2.1 \pm 0.1$ & $2.6 \pm 1.3$ & $0.0 \pm 0.0+\dagger$ & $0.0 \pm 0.0+\dagger$ & $0.0 \pm 0.0 \dagger \dagger$ \\
Microsomes & $11.7 \pm 5.2$ & $25.2 \pm 2.1 \#$ & $14.0 \pm 1.3$ & $0.0 \pm 0.0+\dagger$ & $0.0 \pm 0.0+\dagger$ & $0.0 \pm 0.0+\dagger$ \\
Supernatant & $38.8 \pm 8.7$ & $46.1 \pm 8.4 \# \#$ & $44.6 \pm 7.8 \# \#$ & $6.5 \pm 1.2+\dagger$ & $0.0 \pm 0.0+\dagger$ & $0.0 \pm 0.0+\dagger$
\end{tabular}

Each value is mean \pm S.E.M. for the rats. Number of rats is shown in parentheses.

Abbreviation used: WKY, Wistar-Kyoto rat; SHR, spontaneously hypertensive rats; SHR-SP, stroke-prone spontaneously hypertensive rats.

Significance of differences: $† p<0.05$ (compared with control WKY); ${ }^{*} p<0.01$ (compared with control SHR); \# $\mathrm{p}<0.05$ (compared with control WKY and SHR-SP); \#\# $\mathrm{p}<0.05$ (compared with control WKY); $\dagger \dagger \mathrm{p}<0.001$ (compared with control values in the same fractions).

\section{Discussion}

The high activity of angiotensin-converting enzyme in the brain and the aorta demonstrated in the present study is consistent with the results reported previously in rat, ${ }^{2)}$ or in humans. ${ }^{6)}$ Our results on the regional distribution of the enzyme activity in the brain, however, are not similar to that described by Yang et al., ${ }^{12)}$ who investigated the subcellular and regional localization of the converting enzyme in the brain using normotensive rat from Sprague-Dawley strain and found the highest activity in the striatum and its microsomal fraction. Although we measured only total activity of the enzyme from five areas of the brain, a considerably high activity was found in the hypothalamus of SHR. The cause of this discrepancy is poorly 
understood, but a difference of species used in the study may partly contribute to it.

When angiotensin II is applied into the brain, it causes rat to drink. ${ }^{13}$ ) On the other hand, inactive decapeptide, angiotensin I, when injected into the anterior diencephalon, was almost as effective as angiotensin II in causing rat to drink water. ${ }^{13)}$ Based on these findings, it is suggested that one of the actions of converting enzyme in the brain is to convert angiotensin I that is synthetized in the brain ${ }^{14)}$ into angiotensin II. Furthermore, it is reported that angiotensin II concentration in cerebrospinal fluid of spontaneously hypertensive rat was significantly higher than in normotensive rat. ${ }^{15)}$ Thus, the enzyme may be of significant importance for regulating the concentrations of angiotensin II that is formed from angiotensin $I$ in the brain, especially in the hypothalamus of SHR. It is unknown, however, why the enzyme activity in the same area of SHR-SP was lesser than that of SHR.

It is noteworthy that the significant increase of the converting enzyme activity occurred with the elevation of systemic blood pressure in SHR and SHR-SP treated with $1.0 \% \mathrm{NaCl}$ drinking solution, while there was no significant change in the activity in normotensive rat treated with the same maneuver. The sites where the enzyme activity significantly increased were the midbrain and the striatum. It seems likely that, as compared with normotensive rat, production of the enzyme in such sites is sensitive to sodium in these hypertensive rats. Although there is no direct evidence that such selective elevation of angiotensin-converting enzyme activity is involved in one of the central mechanisms of development of sodium-induced hypertension, this local enhancement of the enzyme activity is possibly substantial for SHR.

The subcellular fractions of the aorta showed the highest activity of the enzyme in the supernatant fraction in WKY, SHR and SHR-SP. On the other hand, it was reported that a large amount of the enzyme was found in the microsomal fraction in swine renal cortex. ${ }^{16)}$ Although the cause of this discrepancy is not clear, a difference of species or the prepared tissues may contribute to it, as well as the brain in our study.

Since angiotensin I forming enzyme, i.e. renin, has been demonstrated in vascular tissue, ${ }^{17}$ the presence of the converting enzyme activity that is widely distributed in the subcellular fractions of the aorta supports the hypothesis that intramural conversion of angiotensin I into II play an important role in the local control of vascular tone. ${ }^{18)}$ As compared with normotensive rat, a greater amount of the total converting enzyme activity was found in the aorta of SHR and SHR-SP. Hence, this increased converting enzyme of 
the aorta might play a role in the local vasoconstriction in the maintenance of hypertension in these hypertensive rats.

The marked decrease of the enzyme activity by sodium intake has been first demonstrated in our study. Although the mechanism cannot be explored in the study, one possible explanation is that the converting enzyme activity is decreased compatibly with the renin-angiotensin axis suppressed by sodium intake. In fact, decrease in renal conversion of angiotensin $I$ was reported in dogs treated chronically with salt and deoxycorticosterone acetate. ${ }^{19)}$ However, it is also possible that sodium can directly suppress the production of the enzyme in the vascular beds. Although there are some unanswered questions, it is very likely that sodium intake lowers the converting enzyme activity of the aorta.

\section{ACKNOWLEDGMENT}

The authors thank to Miss Motoko Ajito for technical assistance. This work was supported, in part, by Grant-in-Aid for Scientific Research from Ministry of Education of Japan.

\section{REFERENCES}

1. Benuck N, Marks N: Subcellular localization and partial purification of a chloride dependent angiotensin-I converting enzyme from rat brain. J Neurochem 30:729, 1978

2. Cushman DW, Cheung HS: Concentrations of angiotensin-converting enzyme in tissues of the rat. Biochim Biophys Acta 250: 261, 1971

3. Grandino A, Paiva A: Isolation of angiotensin-converting enzyme without kininase activity in hog and guinea pig plasma. Biochim Biophys Acta 364: 113, 1974

4. Gocke DJ, Gerten MS, Sherwood LM, Laragh JH: Physiological and pathological variations of plasma angiotensin II in man. Circulat Res 24 (Suppl I): 1, 1969

5. Oparil S, Sanders C, Haber E: In vivo and in vitro conversion of angiotensin I to II in dog blood. Circulat Res 26: 591, 1970

6. Poth MM, Heath RG, Ward M: Angiotensin-converting enzyme in human brain. J Neurochem 25: 83, 1975

7. Vane JR: Sites of conversion of angiotensin I. In hypertension 1972, ed. by J. Genest and E. Koiw, pp 523-532, Springer-Verlag, New York, 1972

8. Glowinski J, Iversen LL: Regional studies of catecholamines in the rat brain. I. The disposition of $\left({ }^{3} \mathrm{H}\right)$ norepinephrine, $\left({ }^{8} \mathrm{H}\right)$ dopamine and $\left({ }^{3} \mathrm{H}\right)$ Dopa in various regions of the brain. J Neurochem 13: 655, 1966

9. Rosenthal J, Paddock J, Hollander W: Identification of a new vasodepressor factor (VDF) in arterial tissue and plasma of dogs and humans. Circulat Res 32-33 (Suppl I): 169, 1973

10. Lowry OH, Rosebrough NJ, Farr AL, Randall RJ: Protein measurement with the Folinphenol reagent. J Biol Chem. 193: 265, 1951

11. Lieberman J: Evaluation of serum angiotensin-converting-enzyme (ACE) level in sarcoidosis. Am J Med 59:365, 1975

12. Yang HYT, Nefr NH: Distribution and properties of angiotensin converting enzyme of rat brain. J Neurochem $19: 2443,1972$ 
13. Fitzsimons JT: The effect on drinking of peptide precursors and of shorter chain peptide fragments of angiotensin II injected into rat's diencephalon. J Physiol (London) 214: 293, 1971

14. Fischer-Ferraro C, Nahmod VE, Goldstein DJ, Finkielman S: Angiotensin and renin in rat and dog brain. J Exp Med 133: 353, 1971

15. Ganten D, Hutchinson JS, Shelling P: The intrinsic brain iso-renin-angiotensin system in the rat: its possible role in central mechanism of blood pressure regulation. Clin Sci Mol Med 48: 265s, 1975

16. Yang HYT, Erdös EG, Levin Y: Characterization of a dipeptide hydrolase (Kininase II: angiotensin I converting enzyme). J Pharmacol Exp Therap 177: 291, 1971

17. Rosenthal J: Effects of aldosterone and spironolactone on arterial renin in rats. Clin Sci Mol Med 51: 121s, 1976

18. Aiken JW, Vane JR: The renin-angiotensin system: Inhibition of converting enzyme in isolated tissues. Nature (London) 228: 30, 1970

19. Franklin WG, Peach MJ, Gilmore JP: Evidence for the renal conversion of angiotensin $\mathrm{I}$ in the dog. Circulat Res 27: 321, 1970 